Cisko L., JUDr., PhD. SITÁR \& SALOKA, Attorneys at Law Košice, Slovak Republic

DOI: https://doi.org/10.30525/978-9934-26-036-0-24

\title{
EUROPEAN UNION STRATEGIES IN THE SPHERE OF ENVIRONMENTAL PROTECTION
}

The aim of this contribution is, in its essence, to approximate the relevant strategies of the European Union focused at halting the loss of biological diversity [1], as well as to set appropriate (effective) legislative solutions related to sustainability, including the transformation of the environmentally friendly food system.

Over the last 40 years was in the field of environmental policy in Europe recorded remarkable success. Since 1970s of the 20th century was introduced a wide range of legislation in the area of environmental protection. In this sophisticated sphere of action, the European Union policy continues to adapt to evolving changes and challenges that have an increasingly global reach $[2$, p. 5]. 
At the same it's need to say that in the area of European Union environmental policy, in order to creating and maintaining (above mentioned) sustainable development, fundamental decisions of the relevant bodies of the European Union are adopting, including legal norms taking into account the European Union's competitiveness, and that from the long-term point of view.

It should be noted that the European Union's environmental policy focuses on a high level of environmental protection, taking into account the diversity of situations in the individual regions of the European Union. It's based on the principles of prevention of damages and prevention, on the principle of remediation of environmental damages at source and on the principle that the polluter pays compensation of damage. A specific question remains that if there has been a significant damage (a certain element) of the environment, whether it's possible to realize the remedy to the original state (restitutio in integrum).

In this context, it's desirable to give attention to legislative solutions, concerning the liability of (particularly) legal persons in the framework of their participation in competition. The caused unfair competitive conduct, in terms of scope and intensity, especially from the side of enterprises [3] (business entities), must be sanctioned according to the seriousness of the act [4].

In its essence, breaching of legislation (not only) in the field of environmental protection is an undesirable phenomenon, which can result up to the criminal law level [5]. Exempli gratia one of the significant consequences of this type of unlawful act of a legal person may be its annulment by a court. Under provisions of $\S 12$ (3) of the Act on Criminal Liability of Legal Persons, by validity of decision, which was imposed a punishment of annulment of the legal person, legal person enters into liquidation [6]. At this place we therefore want to emphasize that a manner to prevent criminal activity (in the broadest sense) could be the form to set up effective sanction mechanisms concentrated (developed) in private law.

The European Green Deal [7, p. 96] is a key strategic framework for achieving the transformation of the European Union into a fair and 
prosperous society with a modern and competitive economy. In terms of content, this is a new growth strategy aimed at using resources efficiently, where net greenhouse gas emissions are to be zero by 2050 and where economic growth will not depend on resource use.

In general, we could define these (economically beneficial) priorities in the relevant normative material, and thus in the legislation. These are in particular secondary law of the European Union [8, p. 159] focusing on effort to the use of renewable energy sources [9], achieving climate stability etc.

In this context need to be mention essentially important material at the supranational level, such as the Proposal for a General Union Environment Action Programme to 2030 [10]. This proposal is intended to confirm the strategic objectives of the European Green Deal and to strengthen the improvement of policy coherence aimed at transforming the European Economic Area (EEA).

A practically integral part of the European Green Deal is the transformation of an environmentally friendly food system. In this context, the European Commission has adopted a new Biodiversity Strategy to 2030 with the proclaimed goal of bringing nature back into our lives [11] and «A Farm to Fork» Strategy [12]. These two strategies are mutually reinforcing, bringing together nature, farmers, business and consumers for jointly working towards a competitively sustainable future [13, p. 1].

In line with the European Green Deal, they propose ambitious European Union actions and commitments to halt biodiversity loss in Europe and worldwide and transform our food systems into global standards for competitive sustainability, the protection of human and planetary health, as well as the livelihoods of all actors in the food value chain. The COVID-19 crisis has demonstrated how vulnerable the increasing biodiversity loss makes us and how crucial a wellfunctioning food system is for our society. The two strategies put the citizen at the centre, by committing to increase the protection of land and sea, restoring degraded ecosystems and establishing the European Union as a leader on the international stage both on the protection of biodiversity and on building a sustainable food chain $[13, \mathrm{p} .1]$. 
Ensuring to the citizens of the European Union's right to a favorable environment (not only) on the basis of the above mentioned facts, means actively and coordinated implementation of the necessary solutions in application practice. In adopting appropriate legislation, special emphasis should be placed on the fact that this issue has in its essence an interdisciplinary nature.

Try to mitigating or (perhaps also) appropriately to circumstances to eliminating persistent problems, must the authorities (already in the nearest time), which have been entrusted the power for adopting functional and effective legislation. At the supranational level, as well as at the level of the Member States of the European Union, they must almost immediately set the highest priorities for strategies (policies) in the framework of their decision-making activities, which will be clearly and distinctly reflecting in the broadest sense the defined principles of environmental protection.

In conclusion must also be said that the effectiveness of all legal norms in the field of environmental protection depends on its proper implementation and enforcement. The European Union over the last 30 years established a solid legislative framework to protect and recovery its natural capital. However, recent evaluations show that, although the legal norms correspond to their purpose, their practical implementation is lagging behind. This has dramatic consequences for biodiversity and are connected with it significant economic costs [14]. For the full implementation and enforcement European Union legislation in the field of environmental protection, must be obtained in a priority the political support and financial and human resources [11]. Some suggestions presented in this article are to be understood only in terms of academic opinions and de lege ferenda proposals.

\section{References:}

1. The term «biological diversity» means the diversity of all living organisms, including their terrestrial, marine and other aquatic ecosystems and the ecological complexes of which they are part. Biological diversity includes diversity in the framework of species, between species and the variousness of ecosystems. In: Article 2 of the Notification of the Ministry of Foreign Affairs of the Slovak Republic on the conclusion of the Convention on Biological Diversity. No. 34/1996 Coll. 
2. Strategic Plan 2016-2020. European Commission. Directorate-General for Environment. 2016.

3. To the conceptual definition of enterprise: KUBÍČEK, P.: Pojem podnik z aspektu práva. In: Obchodné spoločnosti - aktuálne otázky a problémy. Plzeň: Aleš Čeněk, 2008, str. 103 a nasl.

4. To these issues mainly: KUBINEC, M.: Základy práva proti nekalej sút'aži. Vysokoškolská učebnica. 1. vydanie. Banská Bystrica: Vydavatel'stvo Univerzity Mateja Bela. Belianum. 2018, 164 s., ISBN 978-80-557-1410-3.

5. To the criminal liability of legal persons (including its exclusion for some legal persons, principles of imposition of punishments and protective measures etc.) see Act No. 91/2016 Coll. on Criminal Liability of Legal Persons and on amendments to certain acts, approved in the National Council of the Slovak Republic on 13 November 2015. This Act entered into force on 1 July 2016. Hereinafter in text referred to as "Act on Criminal Liability of Legal Persons".

6. To the commercial and legal aspects in the sphere of entrepreneurial activities of legal persons, see in this context: ĎURICA, M.: Likvidácia spoločnosti: $§ 70-75 a$. In: Obchodný zákonník: Komentár. 4. aktualizované vydanie. Bratislava: C.H. Beck, 2013, str. 351 a nasl., ISBN 978-80-89603-12-1.

7. Communication from the Commission to the European Parliament, the European Council, the Council, the European Economic and Social Committee and the Committee of the Regions. The European Green Deal. COM/2019/640 final. European Commission. Done at Brussels, 11 December 2019. Hereinafter in text referred to as "European Green Deal". At this place, we want to point out that the power of the European Commission's legislative initiative doesn't extended only to the procedural aspects (to the right to submit a proposal for a legal act), but also in a material context that is to have the right to determine its content. In: JÚDA, V.: Rozsah a limity právomoci Komisie pri prijímaní záväzných právnych aktov Únie. In: FINĎOVÁ, E. (ed.): Nové trendy v práve I. Zborník príspevkov z medzinárodnej vedeckej konferencie konanej 7-8 apríla 2016 na Právnickej fakulte Univerzity Mateja Bela v Banskej Bystrici. Právnická fakulta Univerzity Mateja Bela v Banskej Bystrici. Banská Bystrica, Belianum, 2016, ISBN 978-80-557-1103-4.

8. At this place we want to mention that the secondary law of the European Union must be secundum et intra legem in accordance with the primary law of the European Union. In: JÚDA, V.: Teória práva. 2. doplnené a podstatne prepracované vydanie. Belianum. Vydavatel'stvo Univerzity Mateja Bela v Banskej Bystrici. 378 s., 2020, ISBN 978-80-557-1689-3.

9. To this see: Consolidated text: Directive 2009/28/EC of the European Parliament and of the Council of 23 April 2009 on the promotion of the use of energy from renewable sources and amending and subsequently repealing Directives 2001/77/EC and 2003/30/EC. Text with EEA relevance. Done at Strasbourg, 23 April 2009. 
10. Proposal for a Decision of the European Parliament and of the Council on a General Union Environment Action Programme to 2030. COM/2020/652 final. Done at Brussels, 14 October 2020.

11. Communication from the Commission to the European Parliament, the Council, the European Economic and Social Committee and the Committee of the Regions. EU Biodiversity Strategy for 2030. Bringing nature back into our lives. COM/2020/380 final. European Commission. Done at Brussels, 20 May 2020.

12. Communication from the Commission to the European Parliament, the Council, the European Economic and Social Committee and the Committee of the Regions. A Farm to Fork Strategy for a fair, healthy and environmentally-friendly food system. COM/2020/381 final. European Commission. Done at Brussels, 20 May 2020.

13. Reinforcing Europe's resilience: halting biodiversity loss and building a healthy and sustainable food system. European Commission - Press release. Done at Brussels, 20 May 2020.

14. The costs of non-implementation are estimated at EUR 50 billion per year. See: The costs of not implementing the environmental acquis. Final report. European Commission. Directorate-General for Environment. September 2011, 169 s. 